\title{
WITHOUT EDUCATION, THERE IS NO PROGRESS: KNOWING TO GROW
}

\author{
M.E. Teixeira \\ Portucalense University, Oporto (PORTUGAL)
}

\begin{abstract}
Underdeveloped countries have a population with low levels of education, which is reserved for those who have more financial possibilities, and who can access to education is still able to achieve higher levels of growth, personal, professional and financial. This factor contributes to widening the inequality gap between the population. However, education is essential for the growth and development of a country, but this is only achieved if the vast majority of the population gets education.
\end{abstract}

Education remains a good springboard for someone to ascend personally and socially. But more than being the means for individual growth, it is also the means that enables a community to achieve better living conditions and to enable the social and economic evolution of the country, making it more competitive and attractive.

Education is fundamental in all sectors, but there is one that can transform a society with direct repercussions on the economic growth of a country, which is financial education. Today, even the most developed countries continue to have some difficulties in economic growth because their population, despite being educated, has no financial knowledge, that is, specialized and technical education in this area is still scarce and this gives a lack of control over the finances of the women. families, who get into more debt than they can afford and ultimately default on their financial commitments. This scenario is detrimental as it does not allow families to reach the levels of financial confort and stability that allow the circulation of capital, which undermines the economic growth of the country.

In this study, we intend to make a study that allows comparative analysis of the relationship between the financial literacy of citizens and their indebtedness and the relationship between this phenomenon and the country's economic growth, concluding that there are three concepts and realities inseparable, and that some are a consequence almost direct from others.

We propose to prove that if there are high levels of financial literacy, the economic growth of the country is higher compared to others and that it is therefore urgent to take steps to include, in the curriculum plans of schools at an earlier age. Financial Literacy discipline and that this need should not only be addressed in the younger age groups but also corrected in the age group of the population who are no longer attending study cycles, but should also be able to attend training on this subject.

Keywords: Education, Financial Literacy, economic growth.

\section{INTRODUCTION}

In this study, we will try to define the concept of financial literacy, distinguishing it from related concepts.

Next, we will analyze the influence and impact that the (existence or absence of) financial literacy of citizens has on the development and economic growth of countries. We propose to demonstrate and prove that the smaller the financial culture of each citizen that makes up the society of a country, the smaller the development of that country and the financial literacy enhances the development of the country. We also propose to demonstrate the status quo of financial literacy in Portugal and to demonstrate the seriousness of the consequences that the unclear assumption of bank responsibilities can have for entire families and thereby drag the entire financial system and economic growth of a country.

\section{METHODOLOGY}

This research study, applying a qualitative research, is based on quantitative data - juridical, legal and social elements - collecting information about the population literacy levels and economic growth in 
different countries. In order to achieve the conclusions, the research is supported in scientific reliable and certified information, analyzed in a comparative methodology to achieve the demonstration of our interpretation. So, our study is supported in an a descriptive / deductive study about the cause / effect concerns of both factors and their relationship.

There are different scientific, official and legal databases / sources of our research, dully studied, since the experts publication / literature to the newest information and details, giving the actuality context to this paper.

\section{DEVELOPMENT}

The family is just a cell of a country's society, so the financial health of each family is an important factor in a country's economic growth. For a country to grow economically, it is imperative that its citizens be able to make sustainable financial decisions without the risk of excessive indebtedness, which ultimately always has repercussions on a country's public accounts, In particular, if we consider that, throughout Europe, but especially in Portugal, in recent years, as a result of the indebtedness of Portuguese families and the consequent non-fulfillment of their financial obligations towards credit institutions, a high level of credit has been generated. This has put the solvency ratio of these institutions into crisis, implying a financial redemption by the State, arguing that if such a redemption were not made, the systemic risk and negative impact of such impairments would arise. Balance sheets of financial institutions would lead to a serious economic downturn in the country. However, it is first of all urgent to delimit the concept of financial literacy.

Understanding economic concepts and their usefulness translates what financial literacy means, which implies knowledge and mastery of basic management and earning knowledge. Saving ability requires managing, budgeting, forecasting, holding and investing. The ability to make financial decisions with confidence means that you have a reasonable level of financial literacy. It is the absence of this knowledge that causes many families to get into too much debt, exceeding the effort rates they can afford. Being able to objectively analyze one's own financial conditions is an advantage for the citizen to ensure his or her own well-being. As the citizen is only a part of the whole, it is important to be informed so that it does not provide debt. Despite the extreme importance that the financial system currently assumes in all sectors of society, most citizens are not aware of the need to know the modus operandi of financial institutions, much less are attracted to the truncated concepts used by these economic agents. There is even an aversion to knowledge and exploitation of these matters by the citizen, even if this means (and often means) contractually binding long years of life and representing a monthly assignment of a substantial part of their income. It is important for the citizen to manage his family budget and apply his savings as properly as possible and this is only possible if the customer knows the products presented to him, to evaluate, in view of his personal and financial conditions. Whether it will be an act of good management or a ruinous act that may contribute to a possible state of insolvency or increased debt level. Bank of Portugal has been developing a series of promotion initiatives and clearer dissemination of information on traded financial products and information on citizens' rights. The most noteworthy initiative in this area resulted in the creation of a citizen portal in the second quarter of 2008. The Portuguese Securities Market Commission has conducted a survey of over fifteen thousand Portuguese families and found that less than ten per cent of these Households hold investments in financial assets, the vast majority being traditional and safer time deposits and savings certificates. They are unaware of investing in stocks, bonds or investment fund units, unaware of their translation and how they operate, much less familiar with derivatives or structured products. This justifies the small share of the share capitalization of Portuguese companies.

It turns out that medium and high risk assets are only subscribed by investors with higher knowledge, the greater the investments the greater the knowledge. The National Council of Financial Supervisors conducted a 2015 survey of the Portuguese population on financial literacy, with the aim of "assessing the three dimensions of financial literacy: attitudes, behaviors, and financial knowledge", trying to categorize the Portuguese population based on their degree of financial inclusion by identifying "the population groups with the highest and lowest levels of financial literacy" by comparing these results internationally. This survey aimed to analyze the behavior, attitudes and financial knowledge of the Portuguese population, following the results that Banco de Portugal reached in its 2010 survey. The intention is to carry out an international comparison exercise of financial literacy levels promoted by International Network on Financial Education (INFE).

This is a key tool for monitoring the evolution of financial literacy levels, as well as the areas and population groups most in need of training. If we look at the report on the results of the Portuguese 
population's financial literacy survey, we find that the vast majority of the population, even those with a mortgage, do not know what the Euribor rate is, and even citizens who have a level of education. Higher education cannot answer the question correctly either, and the same scenario happens with the question of what the spread consists of, unaware of the majority of the population, even those who have mortgage loans, that the spread is the percentage that falls. on a reference interest rate. Interestingly, forty-five percent of respondents in this survey consider retirement savings plans to be low risk applications, which is not necessarily true given that some of them may be based on equity and bond funds, already considered themselves to be at high risk. We can still distinguish between two main groups of people. Those with higher financial literacy rates and those with lower financial literacy rates, analyzing the main differences between the people in these groups.

It is important to analyze this data, since, while it is true that the bank customer cannot and should not be treated as a fool, neither can one ignore and disregard differences of understanding and understanding that derive from various factors, such as the degree of education., the surrounding economic environment, age group, geographical location, individual risk profile and even the professional field in which the bank customer is inserted. The language used by banking institutions contains tight technical concepts, many of which are difficult to grasp, even for individuals who, being highly educated, do not operate in any area that is even related to the banking sector.

In the context of these surveys, it was concluded that there are two large groups of people, those with the best and worst financial literacy results. Individuals with a degree or more, earning more than one thousand euros, credit card holders and using homebanking have the best results, while those who do not have even primary education, seventy or more years old, without bank account, do not They are familiar with homebanking and consider household budget planning to be the least important, which have achieved the worst results. Worldwide, in 2019, according to the Human Development Index, produced each year by the United Nations Development Program, the fifteen most developed countries in the world were Norway, Switzerland, Ireland, Germany, Hong Kong, Australia, Iceland, Sweden, Singapore, the Netherlands, Denmark, Finland, Canada, New Zealand, the United Kingdom, and the United States. The least developed countries in the world in the same year were Niger, Central African Republic, Chad, South Sudan, Burundi, Mali, Eritrea, Burkina Faso, Sierra Leone and Mozambique. The Standard \& Poor's Ratings Services Global Financial Literacy Survey is world's largest survey of the population's financial knowledge. The survey is based on more than 150,000 interviews with adults in over 144 countries. Interestingly, the countries with the highest literacy levels (over $65 \%$ of the population have adequate financial knowledge) are Australia, Canada, Denmark, Finland, Germany, Israel, the Netherlands, Norway, Sweden, and the United Kingdom. In a simple and immediate comparison, we find that most of these countries are part of the 15 most developed countries in the world. At European Union level, Portugal is the second country with the least financial literacy, just ahead of Romania.

According to the Program for International Student Assessment, however, it can be seen that literacy levels among younger people are higher than in the older age group, which gives us a good insight into the future. A country's growth policy must therefore always go through a significant investment in financial education from an early age, implementing financial content in school curricula, and teaching the population early on how to manage their income and investments in order to provide a sustainable economic growth and development of the country, thus increasing the standard of living of the population.

\section{CONCLUSIONS}

We conclude, therefore, that in all segments of life "knowledge has no place" and the citizen has the undeniable right to information and education, but it is also his duty to seek this information and education. You can't and can't teach those who don't seek knowledge.

It is undeniable that bank customers have different levels of understanding. Thus, it is necessary, in fact, to adjust the obligations of banks to the level of understanding of the bank customer.

Given the damaging effects that the whole of Europe felt after the 2007 financial crisis that broke out in the United States of America, concrete training measures for financial inclusion should already have been laid down, even starting from the results of the inquiries carried out by the entities. Financial system supervisors, who would serve as a diagnosis. It is not enough to obtain and analyze results, we must take corrective measures and implement them. The measures that have been taken are aimed at increasing the level of supervision of economic agents, but the solution must be based on the 
bottom up, ie if we provide the population with greater knowledge, the supervision of those agents will naturally be done by the recipients of the financial products.

\section{REFERENCES}

[1] T. Saraiva, "Perfil de risco do investidor: diferenças entre homens e mulheres", Cadernos do Mercado de Valores Mobiliários, n. ${ }^{\circ}$ 40, p. 69, 2011.

[2] S, Schagen, "The evaluation of Natwest Face 2 Face with Finance", National Foundation for Educational Research, 1997.

[3] E. S. M. SILVA, Da responsabilidade pré-contratual por violação dos deveres de informação. Coimbra: Almedina, 2006.

[4] C. C PINA, Dever de informação e responsabilidade pelo prospecto no mercado primário de valores mobiliários. Coimbra: Coimbra Editora, 1999.

[5] J. C. SILVA, Banca, Bolsa e Seguros, Tomo I - Direito Europeu e Português. Coimbra: Almedina; 2013. 